\title{
The Fishery of Portunus pelagicus and Species Diversity of Portunid Crabs along the Coast of Dar es Salaam, Tanzania
}

\author{
A.I. Chande ${ }^{1}$ and Y.D. Mgaya ${ }^{2}$ \\ ${ }^{1}$ Tanzania Fisheries Research Institute, P.O. Box 9750, Dar es Salaam, Tanzania; ${ }^{2}$ Faculty of Aquatic \\ Sciences and Technology, University of Dar es Salaam, P.O. Box 35064, Dar es Salaam, Tanzania
}

Key words: Portunid crabs, production, species diversity, habitat preference

\begin{abstract}
Production, habitat preference and distribution of the blue swimming crab, Portunus pelagicus and the diversity of portunid crabs were studied along the Dar es Salaam coastline, Tanzania. Samples were obtained from beach seine nettings and basket traps. The samples from basket traps were used in habitat preference studies only. The production of Portunus pelagicus was assessed in terms of catch rate and biomass, and the biomass and contribution of recruits to the stock estimated using the Leslie method. Seasonal variations in catch rate were found, with peaks between December and May. The highest catch rate was recorded at Msasani Bay (2.24 kg/haul/100-m net), and the lowest at Mzinga Creek (1.08 kg/haul/100-m net). The harvestable biomass for Dar es Salaam coast on average was 34.5 tonnes/year, while the contribution of recruitment to the biomass was about 20.2 tonnes/year. Portunus pelagicus was the most abundant portunid in all the sites, comprising between 39.1 and $81.5 \%$ of the catches at Mzinga Creek and Kunduchi respectively. Charybdis anisodon, Scylla serrata and Portunus sanguinolentus were also found in various proportions at the sites. Generally there was a significant difference in species diversity between sites, with $P$. pelagicus showing a high preference for the sub-littoral shallow waters. For rational exploitation of this crab, management measures based on the estimated harvestable biomass and the size at first maturity are recommended.
\end{abstract}

\section{INTRODUCTION}

The blue swimming crab, Portunus pelagicus (L.) represents a valuable component of small-scale coastal fisheries in many countries in the tropics (Batoy et al., 1980; Joel \& Raj, 1987; Kyomo, 1999; Mgaya et al., 1999). Its distribution extends from the southern Mediterranean Sea, the east coast of Africa and across the Indian Ocean to Japan and the western Pacific Ocean (Smith, 1982; Potter et al., 1983). The crabs are harvested using traps, beach seine nets and bottom-set gillnets (Heath, 1973; Bwathondi \& Mwaya, 1985; Haefner, 1985).

The dominant fishery along the coastal waters of Tanzania is artisanal in nature, operating gillnets, sharknets, beach seine nets, cast nets, basket traps and hook and line (Mgaya et al., 1999). The catch from various types of gear is composed of both finfish and crustaceans.

Assessment of stock is important for the management of any fishery. Different models are used to assess the stock, but the surplus production model, which uses catch per unit of effort, is the most commonly used tool for generating immediate data for an exploitation and development strategy (Ricker, 1975; Sparre \& Venema, 1992).

Portunus pelagicus lives in association with other portunid crabs whose contribution to the total crab catches is important both economically and 
ecologically. In Tanzania only two species of crab are large enough to have fishery potential; these are P. pelagicus and Scylla serrata (Heath, 1973; Bashemererwa, 1981; Mwaiseje, 1982; Siegel, 1986).

Despite the high fishery potential of $P$. pelagicus in Tanzania, there is no up to date information on its fishery status, and available data are questionable. For example, the monthly harvestable crab biomass in the Rufiji area was estimated at 20.64 tonnes (Alverson \& Patterson, 1974), which is a gross underestimation (Richmond et al., 2002). No previous studies have been conducted in sufficient detail to provide reliable estimates of the available stock and its rate of exploitation.

The objectives of the study reported here were to assess production, determine habitat preference and size distribution of P. pelagicus, and establish the diversity of portunid crabs along the Dar es Salaam coast.

\section{MATERIALS AND METHODS}

\section{Sample and data collection}

Samples for the study were obtained from beach seine nets operated by fishermen from Mzinga Creek, Msasani bay and Kunduchi sub-littoral open shallow waters (Fig. 1). The sizes of beach seine nets ranged between 30 and $100 \mathrm{~m}$ in length and $19 \mathrm{~mm}$ stretched mesh size in the cod end. The frequency of sampling was five days per site per month for a period of two years, 1995 and 1996.

The specimens were collected from hauls made by different fishing units. The sample size per haul depended on the size of the catch; if small, all individual crabs were collected and if large, the crabs were first separated from fish and a subsample of crabs was then taken by dividing the unsorted heap into equal proportions. The sample was sorted into different species which were then counted and weighed. The carapace width of $P$. pelagicus was measured (to the nearest $0.1 \mathrm{~mm}$ ) to obtain the size frequency distribution for recruitment pattern estimates. The total catch of $P$. pelagicus was also recorded.

Studies on habitat preference and size distribution of $P$. pelagicus were carried out in three habitats at Kunduchi during 1995, namely the creek, sub-littoral open shallow waters of about 4-m depth, and below and sub-littoral deep waters ranging between 4 and $10 \mathrm{~m}$ in depth.

Samples from the deep waters where beach seine nets could not operate were obtained by using basket traps. The traps measured $69 \mathrm{~cm}$ in length, $61 \mathrm{~cm}$ in width and $17 \mathrm{~cm}$ in height with a mesh size of $2.5 \mathrm{~cm}$. The traps were set in areas surrounding Mbudya and Pangavini islands (Fig. 1). Traps were also set in shallow waters off the old Africana Hotel where disturbance from beach seine net operations was minimal. This aimed at eliminating the factor of gear selectivity. Ten traps were used; five were set in the deeper waters while the other five were set in shallow waters. The traps were baited with fish offal and were left overnight and hauled the following morning. Fishing was conducted for three days per month. The production was assessed from the catch rates and biomass estimates. The seine nets lengths were standardised to $100 \mathrm{~m}$ to give catch rates in $\mathrm{kg} /$ haul/100-m net.

\section{Biomass estimation}

Biomass was estimated using the Leslie method (Bailey \& Elner, 1988), since other models developed for the estimation of finfish stocks from age, mortality and growth parameters are inappropriate when applied to crustaceans (Otto, 1986; Edwards, 1988). The Leslie technique relies on a declining trend in catch per unit effort over the fishing season. Since the habitats for $P$. pelagicus were under high exploitation by beach seine net operations, the drop in catch per unit effort over a season was significant.

The monthly mean values of catch per unit of effort were plotted against the cumulative catch for all beach seine nets fishing in the sites. A period of one year was taken as the fishing season. Total catch was estimated from the total number of boats fishing with beach seine nets in the three sites. The number of nets was multiplied by the average daily number of hauls (i.e. 3) each unit operated. The product was multiplied by 25 days, which was the average number of fishing days per month. Then the product was multiplied by the sample catch per unit of effort.

The catch per unit of effort and the cumulative catch were fitted to a regression line using the 


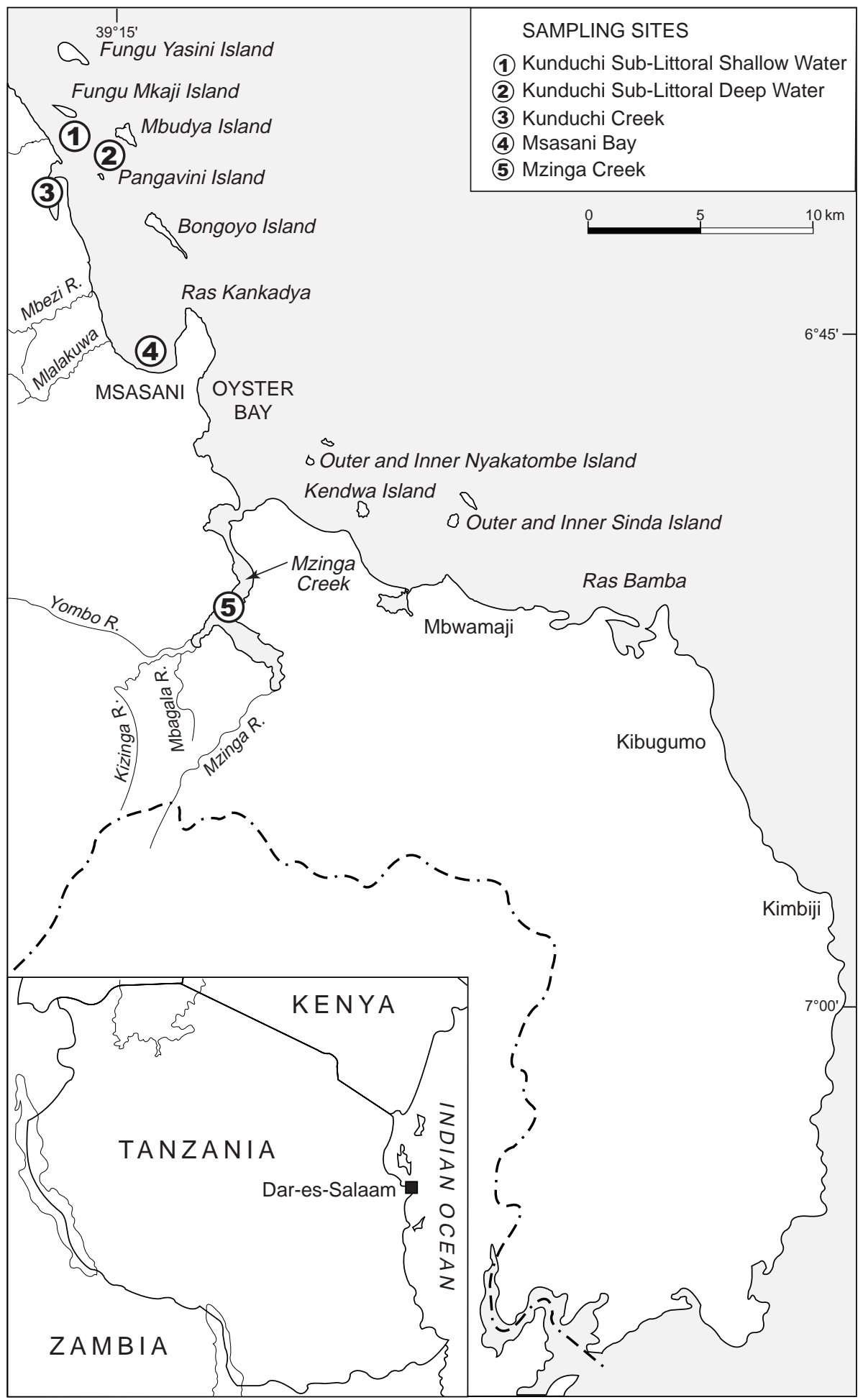

Fig. 1. Map of Dar es Salaam coastal area showing sampling sites. Inset: Dar es Salaam coastline 
equation (King, 1995):

$$
C P U E_{t}=q B_{o}-q \Sigma c_{t}
$$

where $C P U E_{t}=$ the mean catch rate over the fishing season (time period $\mathrm{t}$ ), $\Sigma \mathrm{c}_{\mathrm{t}}=$ the cumulative catch up to the middle of the same time period $t, q=$ catchability, the fraction of the exploitable biomass captured by a single net haul, estimated by the slope of the regression line, and $\mathrm{qB}_{\mathrm{o}}=$ the intercept on $\mathrm{y}$ axis.

The total exploitable biomass $\mathrm{B}_{\mathrm{o}}$, was estimated by dividing $\mathrm{qB}_{\mathrm{o}}$ by $\mathrm{q}$. $\mathrm{B}_{\mathrm{o}}$ corresponds to the intercept of the regression line on the $\mathrm{x}$-axis. The biomass present at any given period $\left(\mathrm{B}_{\mathrm{t}}\right)$ was estimated using the following equation (King, 1995):

$B_{t}=\frac{C P U E_{t}}{q}$

This is the estimated initial biomass during the fishing season. The increase of biomass from growth and recruitment during the fishing season was calculated from the total harvestable biomass $\left(\mathrm{B}_{\mathrm{o}}\right)$ minus the initial biomass $\left(\mathrm{B}_{\mathrm{t}}\right)$.

\section{Data analysis}

Single factor analysis of variance was used to test whether there were seasonal variations in catch rates in each site. The assumptions underlying ANOVA include homoscedasticity of variances and normally distributed residual variation (Zar, 1999). Data were first tested for homoscedasticity before employing ANOVA and where variances were not normal and homogeneous, arcsine transformation was performed and homoscedasticity was reassessed. This procedure ensured that the assumptions of analysis of variance were not violated. Analysis of variance was also carried out to detect any variations in catch rates among sites. Shannon-Weaver diversity indexes for different sites during the two years of study were compared using a t-test (Magurran, 1983). The distribution of portunid crabs in different habitats were compared using Cochran's Q test (Cochran, 1950; Zar, 1999). Differences at $\mathrm{P}<0.05$ were considered significant.

\section{RESULTS}

\section{Production of Portunus pelagicus}

\section{Catch rates}

Monthly catch rates of $P$. pelagicus using beach seine nets from different sites during the two years of study are presented in Fig. 2. Since the beach seine nets were of different sizes, the catch rates were calculated at a standardised $100 \mathrm{~m}$ net size. As the catch rates for males and females were not significantly different $\left(\mathrm{F}_{(1,222)}=0.002, \mathrm{P}=0.932\right)$, the data for the two sexes were pooled.

During 1995, the catch rates were high between

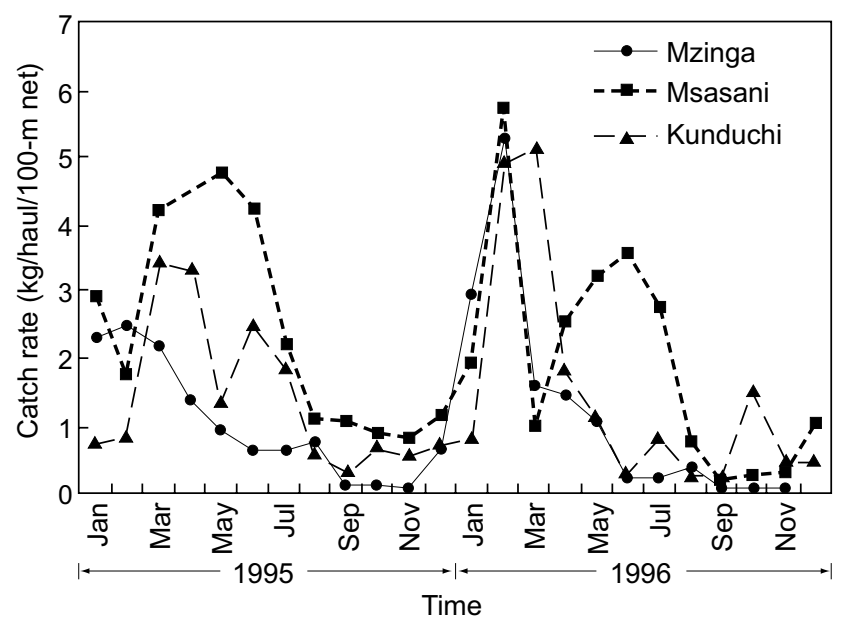

Fig. 2. Monthly catch rates of Portunus pelagicus from different sites during 1995 and 1996 
January and July, except at Mzinga creek where high catch rates were recorded between January and May. During 1996 high values were recorded between January and May but at Msasani they were recorded up to July. Both years had high catch rates in December. The variations in catch rates were seasonal, as seen in Fig. 2.

There were also variations in catch rates among sites during $1995\left(\mathrm{~F}_{(2,237)}=7.473, \mathrm{P}=0.001\right)$. Mzinga creek recorded the lowest $(1.08 \mathrm{~kg} / \mathrm{haul} /$ $100-\mathrm{m} \mathrm{net}$ ) and Msasani the highest $(2.11 \mathrm{~kg} / \mathrm{haul} /$ 100-m net). During 1996 there were no variations among sites $\left(\mathrm{F}_{(2,183)}=2.321, \mathrm{P}=0.101\right)$. The highest mean catch was recorded at Msasani (2.24 $\mathrm{kg} / \mathrm{haul} / 100-\mathrm{m} \mathrm{net}$ ) and the lowest at Mzinga creek (1.41 kg/haul/100m-net). Catch data from Kunduchi creek and those from traps were small with the mean value for the catch rate from Kunduchi creek being $0.53 \mathrm{~kg} / \mathrm{haul} / 100-\mathrm{m}$ net. The catch rates from traps were $0.07 \mathrm{~kg} /$ trap for the sub-littoral shallow waters and $0.02 \mathrm{~kg} /$ trap for the deep waters.

\section{Biomass estimation}

The biomass of $P$. pelagicus along the coast of Dar es Salaam during 1995 and 1996 was estimated using the regression lines presented in Figs $3 \mathrm{a}$ and b respectively.

For 1995 the regression equation was calculated from the basic equation: $C P U E=q B_{o}$ - $q \Sigma C t$, as $C P U E=3.5-\left(1.0 \times 10^{-4}\right) \Sigma C$.

From the data, $\Sigma C=18,042 \mathrm{~kg}$, thus $C P U E=1.70 \mathrm{~kg} / \mathrm{haul} / 100-\mathrm{m}$ net.

The harvestable biomass, $B_{o}=q B_{o} / q=3.50 /$ $1.0 \times 10^{-4}=35,000 \mathrm{~kg}$, corresponding to the intercept of the regression line on the $\mathrm{x}$ axis (Fig. $3 a)$.

The estimated initial biomass $=C P U E / q=$ $1.70 / 1.0 \times 10^{-4}=17,000 \mathrm{~kg}$.

The increase of biomass from growth and recruitment during the fishing period was:

$\mathrm{B}_{\mathrm{t}}=$ harvestable biomass $\left(\mathrm{B}_{\mathrm{o}}\right)-$ initial biomass $=35,000 \mathrm{~kg}-17,000 \mathrm{~kg}=18,000 \mathrm{~kg}$.

For 1996 the regression equation was: $C P U E=4.4-\left(1.3 \times 10^{-4}\right) \Sigma C$.

From the data, $\Sigma C=21,984 \mathrm{~kg}$, thus $C P U E=1.50 \mathrm{~kg} / \mathrm{haul} / 100 \mathrm{~m}$-net.

The harvestable biomass $\left(B_{o}\right)=q B_{o} / q=4.4 /$ $1.3 \times 10^{-4}=33,846 \mathrm{~kg}$, corresponding to the intercept of the regression line on the $\mathrm{x}$ axis (Fig. $3 b)$.

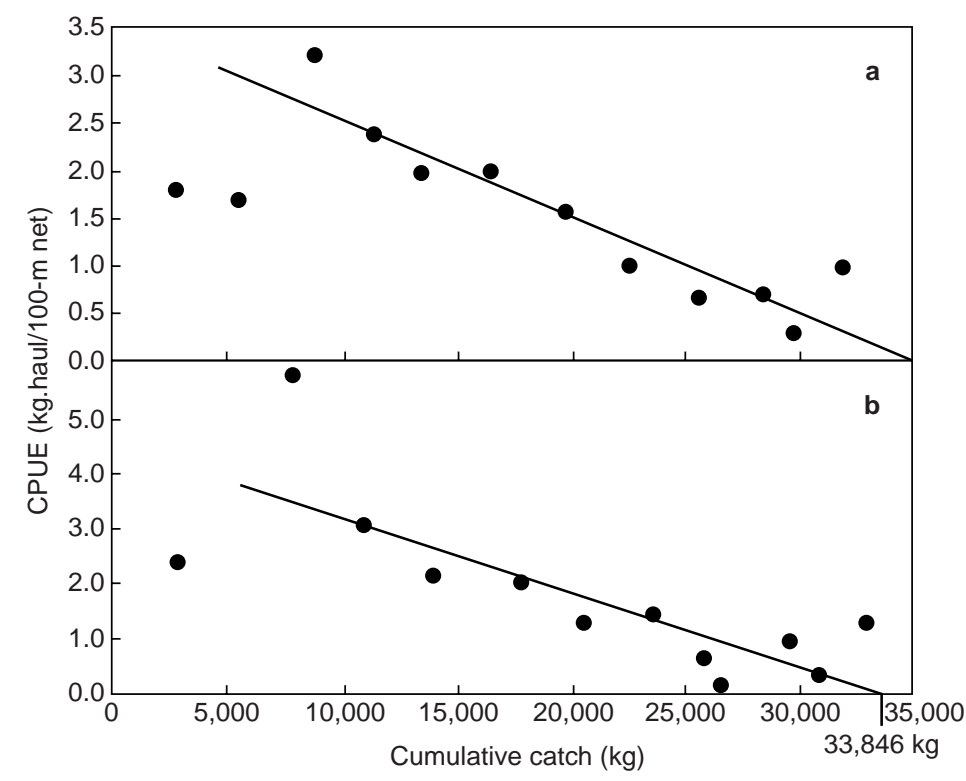

Fig. 3. Estimation of harvestable biomass of Portunus pelagicus in Dar es Salaam coastal waters during 1995 (a) and 1996 (b) by Leslie method using catch per unit of effort (CPUE) and cumulative catch 
The estimated initial biomass $=C P U E / q=$ $1.50 / 1.3 \times 10^{-4}=11,538 \mathrm{~kg}$.

The increase of biomass from growth and recruitment during the fishing period, $\mathrm{B}_{\mathrm{t}}=$ harvestable biomass $\left(\mathrm{B}_{\mathrm{o}}\right)$ - initial biomass $=$ $33,846-11,538=22,308 \mathrm{~kg}$.

The results during the two years show that the harvestable or commercial biomass decreased from 1995 to 1996 by $3.3 \%$, and the initial biomass at any particular time during the fishing season decreased by $32.1 \%$. The increase of biomass from recruitment and growth was higher during 1996 than in 1995 by $23.9 \%$.

\section{Portunid crab species composition, diversity and distribution}

Table 1 shows the portunid crab species composition in beach seine catches from the three study sites during 1995 and 1996. There were 11 species in all sites at Mzinga creek, three species -Portunus pubescens, P. orbitospinus and Charybdis natator - were uncommon. The latter species was also uncommon at Msasani. Charybdis anisodon, T. crenata and $C$. helleri were absent at Kunduchi.

Portunus pelagicus was the most abundant in all sites during the entire study period. The highest value was recorded at Kunduchi $(81.5 \%)$ during 1996, while the lowest was recorded at Mzinga creek $(39.1 \%)$ during 1995 . The second most abundant species at Mzinga creek was Charybdis anisodon followed by Scylla serrata. Portunus sanguinolentus was the second in abundance both at Msasani and Kunduchi.

The general distribution of the species among the sites during 1995 and 1996 showed no significant difference as indicated by Cochran's $\mathrm{Q}$ test, $(\mathrm{Q}=2.333, \mathrm{df}=2, \mathrm{P}>0.05$ and $\mathrm{Q}=0.286$, $\mathrm{df}=2, \mathrm{P}>0.05$ respectively). However, the species diversity as indicated by the Shannon-Weaver index and tested by Student's t-test had significant differences between years except at Mzinga creek (Table 2). There were also significant differences between sites $(\mathrm{P}<0.001)$.

\section{Habitat preference and size distribution of Portunus pelagicus}

The habitat preference of $P$. pelagicus was analysed using 1995 data from Kunduchi sites, namely the creek, sub-littoral shallow waters and sub-littoral deep waters. These sites were selected because they are in close proximity, so that any differences could be attributed to factors other than distance apart. The mean catch rates from beach seine nets for Kunduchi sub-littoral shallow waters was higher $(1.45 \mathrm{~kg} / \mathrm{haul} / 100-\mathrm{m}$ net) than that of Kunduchi creek $(0.53 \mathrm{~kg} / \mathrm{haul} / 100-\mathrm{m}$ net). The mean catch rates from traps for sub-littoral shallow waters was also higher $(0.07 \mathrm{~kg} / \mathrm{trap})$ than that of deep waters $(0.02 \mathrm{~kg} / \mathrm{trap})$. These results suggest that sublittoral shallow water is the most preferred habitat for P. pelagicus.

Table 1. Portunid crab species composition caught by beach seine nets from different sites along the Dar es Salaam coastline in 1995 and 1996

\begin{tabular}{|c|c|c|c|c|c|c|}
\hline \multirow[b]{3}{*}{ Species } & \multicolumn{6}{|c|}{ Percent composition } \\
\hline & \multicolumn{2}{|c|}{ Mzinga } & \multicolumn{2}{|c|}{ Msasani } & \multicolumn{2}{|c|}{ Kunduchi } \\
\hline & 1995 & 1996 & 1995 & 1996 & 1995 & 1996 \\
\hline Portunus pelagicus & 39.1 & 41.8 & 71.9 & 63.0 & 73.0 & 81.5 \\
\hline P. sanguinolentus & 2.5 & 0.5 & 26.2 & 35.4 & 18.1 & 17.2 \\
\hline P. pubescens & - & - & 0.2 & 0.5 & 8.5 & 0.9 \\
\hline P. orbitospinus & - & - & - & 0.1 & 0.2 & 0.1 \\
\hline Thalamita crenata & 8.7 & 11.8 & 0.1 & 0.4 & - & - \\
\hline Charybdis anisodon & 31.5 & 22.5 & 1.0 & 0.3 & - & - \\
\hline C. cruciata & 0.1 & 0.1 & 0.1 & 0.3 & 0.1 & 0.1 \\
\hline C. helleri & 0.3 & 0.7 & 0.1 & 0.1 & - & - \\
\hline C. natator & - & - & - & - & - & 0.1 \\
\hline Scylla serrata & 17.9 & 22.5 & 0.4 & - & 0.1 & 0.1 \\
\hline Podophthalmus vigil & - & 0.1 & 0.1 & 0.1 & - & 0.1 \\
\hline
\end{tabular}

,- not found. 
Table 2. Shannon-Weaver diversity index $\left(H^{\prime}\right)$ of portunid crab species caught by beach seine nets in different sites during 1995 and 1996

\begin{tabular}{lccccc}
\hline Site & Year & $\mathrm{H}^{\prime}$ & $\mathrm{df}$ & $\mathrm{t}$ & $\mathrm{P}$ \\
\hline Mzinga & 1995 & 1.364 & 8000 & 0.50 & $>0.50 \mathrm{~ns}$ \\
& 1996 & 1.357 & & & \\
Msasani & 1995 & 0.690 & 6667 & 3.10 & $<0.002^{*}$ \\
& 1996 & 0.752 & & & \\
Kunduchi & 1995 & 0.774 & 2500 & 8.25 & $<0.001^{*}$ \\
& 1996 & 0.543 & & & \\
\hline
\end{tabular}

ns, not significant at $\mathrm{P}>0.05$; *, significant difference at $\mathrm{P}<0.05$.

The size distribution of $P$. pelagicus suggests that both small and large individuals inhabit the sub-littoral shallow waters. The data for the creek and deep waters were few hence they are not presented. However, the catches in the creek ranged from small- $(1.5 \mathrm{~cm})$ to large-sized individuals $(11.5 \mathrm{~cm})$ while those from the deep waters included only large individuals. The length of males was $10.5-12.5 \mathrm{~cm}$ and that of females $9.4-12.7 \mathrm{~cm}$.

\section{Recruitment pattern of Portunus pelagicus}

The annual recruitment pattern was similar at all three sites, consequently, data for all sites were pooled. Since maturity stages analysis showed that crabs of $5.5 \mathrm{~cm}$ or below were immature, they were thus considered as new recruits in this study. Generally young crabs were recruited throughout the year with distinct peak periods. There were two peaks during both 1995 and 1996. The first peak was between January and June while the second one was in December 1995 and between November and December in 1996.

\section{DISCUSSION}

\section{Production of Portunus pelagicus}

\section{Catch rates}

The present study has revealed seasonality in the catch rates of $P$. pelagicus, similar to trends reported elsewhere. For example, Devi (1985) found that crab fishery in Kakinada region, India was year round with peak periods from April to
May and August to November. Mgaya et al. (1999) reported high crab catches between January and May in Bagamoyo coastal waters, pointing to a rainy-season peak.

In the present study peak crab catches occurred between December and May, coinciding with the peak period for recruitment. Much of this period experiences the Northeast monsoon and is characterised by high abundance of phytoplankton and zooplankton (Bryceson, 1982) which might support the early planktonic forms (zoeae) of the crab. The high abundance of phytoplankton and zooplankton during this period is attributable to the stable thermocline, a result of calm conditions which prevail during the period (Newell, 1957; 1959).

Studies on seasonal catches of finfish in Tanzania have shown that the catch is low during the Southeast monsoon and high during the Northeast monsoon with a peak in March at the end of the NE monsoon (Newell, 1957; 1959; Morgans, 1962; McClanahan, 1988). The seasonality was attributed to fish migrations and decreased density and activity due to a deeper thermocline and cooler waters in the Southeast monsoon (Newell, 1957; McClanahan, 1988). The seasonality in the catches of $P$. pelagicus could be attributed to similar factors. It is likely that adult crabs could have migrated to deeper waters. This is supported by catches from traps set in deep waters at Kunduchi, recorded in August and September during Southeast monsoon.

Seasonal fluctuations in $P$. pelagicus densities influenced by an offshore migration were also reported by Edgar (1990) in Western Australia. Another factor which might have played a role in the decrease of catches during the Southeast monsoon could be growth overfishing, resulting from the capture of juvenile crabs which are usually discarded.

The low catches recorded at both Mzinga and Kunduchi creeks could be attributed to a number of factors. In the case of Mzinga creek the reason could be the variations in salinity resulting from several rivers flowing into the creek (see Fig. 1). Other parameters such as oxygen and temperature were almost similar in all sites. For example, the mean values of dissolved oxygen ranged between 3.72 and $4.53 \mathrm{mg} / \mathrm{l}$ and were not significantly 
different $\left(\chi^{2}=0.114, \mathrm{df}=3, \mathrm{P}=0.990\right)$. The low catches recorded at Kunduchi creek could be influenced by the nature of the habitat. During the low tide, much of the water goes back to the sea leaving only scattered pools, which could harbour the crabs. Since the water becomes very shallow during low tide, surface water temperatures were very high (measured up to $33^{\circ} \mathrm{C}$ in January 1995), which could be unfavourable for the crabs. As a result crab species were abundant at the mouth of the creek, where conditions were more favourable.

\section{Biomass estimation}

Generally, the available harvestable biomass was small and the catches were dominated by smallsized individuals, and it may therefore be concluded that growth overfishing had set in in the study area. Recruitment overfishing was not evident, presumably because spawners are known to migrate to less disturbed, deeper waters (King, 1995) where beach seine nets are not operated. Consequently, the deeper waters may act as a reservoir for spawners, and contribute many recruits to the population.

The increase in the contribution from growth and recruitment between the two years of study implies that the fishery is capable of recovering from the effects of overfishing. Furthermore, the proportion of individuals that were added to the population was higher than the decrease in harvestable biomass in subsequent years, signifying that the fishery would take long to collapse if maintained at present levels.

Nhwani et al. (1993) reported on the destruction caused by the activity of beach seiners. They found that beach seine nets caught juvenile prawns at Mzinga creek, and recommended the use of gill nets of $63.0 \mathrm{~mm}$ stretched mesh. The present study adopted the mesh size recommendation by Nhwani et al. (op. cit.) to safeguard the fishery of this crab. This will ensure that only reproductively mature crabs are harvested.

\section{Portunid crab species composition, diversity and distribution}

Our percentage species composition data shows that $P$. pelagicus was the most important portunid crab along the coast of Dar es Salaam and was abundant in all habitats. This could be attributed to its ability to tolerate a wide range of salinity, from 9.0 to $39 \%$ and the abundance of its common food item, the bivalve Arcuatula arcuatula, in all habitats (Chande, 1999). Although the distribution of species between the three habitats was not significantly different, some species showed clear preferences for some habitats. For example, Charybdis anisodon and Thalamita crenata were more common in estuarine conditions, suggesting a preference for low salinity. Portunus pubescens and $P$. orbitospinus were uncommon in the estuary, and instead were abundant at Kunduchi and Msasani where conditions were more oceanic. Previous studies (e.g. Heath, 1973) on portunid crabs at Kunduchi reported two species, namely $P$. gladiator and P. argentatus not recorded in the present study. Likewise, two species recorded in the present study, $P$. pubescens and P. orbitospinus were not reported by Heath (1973). The differences on the species composition between the two studies could be attributed to differences in gears used and temporal variations.

\section{Habitat preference and size distribution of Portunus pelagicus}

The abundance of $P$. pelagicus was compared among the three sites at Kunduchi. The sub-littoral shallow water of $0.5-4 \mathrm{~m}$ depth was the most preferred site, as indicated by the high catch rates of different-sized crabs ( 3.5 to $13.5 \mathrm{~cm}$ for males and 2.5 to $12.5 \mathrm{~cm}$ for females). The deep waters off the creek recorded poor catches which comprised mainly of large individuals. The creek had different-sized crabs, but the catches were low.

Small $P$. pelagicus are reported to prefer shallow waters while big ones migrate to deep waters (Joel \& Raj, 1987). The Dar es Salaam coastal habitat was found to be suitable for all sizes. The creek is tidal and during low tide much of the water goes back to the sea, making the substratum unsuitable for burrowing, as substrate surface temperatures can be quite high (e.g. $33{ }^{\circ} \mathrm{C}$ in January 1995). The differences in the distribution of $P$. pelagicus in different habitats according to size could be related to their swimming ability, as large individuals can tolerate strong waves in 
deeper waters. Another possible explanation could be related to breeding migration, whereby ovigerous females migrate to a more oceanic environment in the deep water (Batoy et al., 1980).

\section{Fishery management of Portunus pelagicus}

The management measures recommended from this study are based on the estimated harvestable biomass and the minimum size at maturity for both females and males, i.e. 8.5 and $8.7 \mathrm{~cm}$, respectively. The decline of the harvestable biomass could be attributed to the large numbers of juvenile crabs caught. Proper management measures could include gear selectivity and mesh size regulation. Selective fishing methods should be encouraged, which include hand picking, gillnets and basket traps while the use of beach seine nets should be avoided. From the sizes at first maturity the gill nets and traps could be about $9.0 \mathrm{~cm}(90 \mathrm{~mm})$ or 3.5 inches in mesh size based on carapace width. Selecting mesh sizes slightly higher than sizes at first maturity allows the crabs to reproduce at least once before being recruited to the fishery. Therefore, $9.0 \mathrm{~cm}$ would be the legal size for capture, as it is higher than the size at first maturity. Another measure could be to return back to the water any juveniles, recently moulted (soft shell) or ovigerous crabs that are caught inadvertently.

These management measures have been recommended elsewhere. Otto (1986) recommended an exploitation rate that never exceeded $60 \%$ of the legal males of the sea king crab in the eastern Bering Sea. Joel and Raj (1987) recommended the protection of the breeding stock and undersized $P$. pelagicus in Pulicat, India, while Muthiga (1986) recommended returning back to the sea of juveniles, ovigerous females and recently moulted crabs as a way of preventing overfishing.

Acknowledgements-We wish to express our sincere thanks to the Swedish Agency for Research and Economic Cooperation with Developing Countries (SAREC) for the generous financial support which made this study possible. Tanzania Commission for Science and Technology $(\mathrm{COSTECH})$ is also acknowledged for providing supplementary research funds for fieldwork. The anonymous reviewer and Dr Gamba Nkwengulila are thanked for their comments.

\section{REFERENCES}

Alverson, F.G. \& Patterson, P.H. (1974) International trade - crabs. International trade-Tuna, shrimp, crab, fish meal, ground fish. FAO, UN Indian Ocean Fish Commission, IOFC/Dev/74/40. 199 pp.

Bailey, R.F.J. \& Elner, R.W. (1988) Northwest Atlantic snow crab fisheries: Lessons in research and management. In: Caddy, J.F. (ed.) Marine invertebrate fisheries: their assessment and management. John Wiley and Sons, New York. pp. 261-280.

Bashemererwa, V. (1981) Some aspects of the biology of Scylla serrata (Forskal) (Crustacea: Portunidae) in Dar es Salaam area. MSc Thesis, University of Dar es Salaam. 126 pp.

Batoy, C.B., Sarmago, J.F. \& Pilapil, B.C. (1980) Breeding season, sexual maturity and fecundity of blue crab, Portunus pelagicus (L.) in selected coastal waters in Leyte and Vicinity, Philippines. Ann. Trop. Res. 9: 157-177.

Bryceson, I. (1982) Seasonality of oceanographic conditions and phytoplankton in Dar es Salaam waters. Univ. Sci. J. (Dar Univ.) 8: 66-76.

Bwathondi, P.O.J. \& Mwaya, G. (1985) The fishery of Crustacea and Mollusca in Tanzania. In: Iversen, S.A. \& Myklevoll, S. (eds) The proceedings of the NORAD-Tanzania seminar to review the marine fish stocks and fisheries in Tanzania, 6-8 March, 1984, Mbegani, Tanzania. Tanzania Fisheries Research Institute, Dar es Salaam, Norwegian Agency for International Development and the United Nations University, Tokyo, Japan, pp. 19-28.

Chande, A.I. (1999) The biology and fishery potential of the crab, Portunus pelagicus (Linnaeus, 1766) along the coast of Dar es Salaam. PhD Thesis, University of Dar es Salaam. 291 pp.

Cochran, W.G. (1950) The comparison of percentages in matched samples. Biometrika 37: 250-266.

Devi, S.L. (1985) The fishery and biology of crabs of Kokinada region. Ind. J. Fish. 32: 18-32.

Edgar, G.J. (1990) Predator-prey interactions in seagrass beds. II. Distribution in diet of the blue manna crab, Portunus pelagicus (L.) at Cliff Head, Western Australia. J. Exp. Mar. Biol. Ecol. 139: 23-32.

Edwards, E. (1988) Crab fisheries and their management in the British Isles. In: Caddy, J.F. (ed.) Marine invertebrate fisheries: their assessment and management. John Wiley and Sons, New York. pp. 241-259. 
Haefner, Jr. P.A. (1985) The biology and exploitation of crabs. In: Provenzano Jr., A.J. (ed.) The biology of Crustacea: economic aspects, fisheries and culture. Academic Press, Orlando. pp. 111-166.

Heath, J.R. (1973) The crabs of Dar es Salaam, Part I: Portunidae. Tanzania Notes Rec. 72: 1-17.

Joel, D.R. \& Raj, P.S.S. (1987) Marine crab fisheries around Pulcat. Seafood Exp. J. 19: 16-24.

King, M. (1995) Fisheries biology, assessment and management. Fishing News Books, Oxford. 341 pp.

Kyomo, J. (1999) Distribution and abundance of crustaceans of commercial importance in Tanzania Mainland coastal waters. Bull. Mar. Sci. 65: 321-335.

Magurran, A.E. (1983) Ecological diversity and its measurements. Chapman and Hall, London. 179 pp.

McClanahan, T.R. (1988) Seasonality in East Africa's coastal waters. Mar. Ecol. Prog. Ser. 44: 191-199.

Mgaya, Y.D., Muruke, M.H.S., Chande, A.I. \& Semesi, A.K. (1999) Evaluation of crustacean resources in Bagamoyo District. In: Howell, K.M. and Semesi, A.K. (eds) Coastal resources of Bagamoyo district Tanzania. Proceedings of a workshop on coastal resources of Bagamoyo, 18-19 December 1997, Bagamoyo. Faculty of Science, University of Dar es Salaam. pp. 55-63.

Morgans, J.F.C. (1962) Ecological aspects of demersal tropical fisheries off East Africa. Nature 193: 86-87.

Muthiga, N.A. (1986) Edible crabs of Kenya. Kenya Aquatic 3: 61-65.

Mwaiseje, B. (1982) The potential for nonconventional fisheries in Tanzania. Univ. Sci. J. (Dar Univ.) 8: 35-42.

Newell, B.S. (1957) A preliminary survey of the hydrography of British East African coastal waters I. Fish. Publ. Lond. 9: 1-21.

Newell, B.S. (1959) The hydrography of British East African coastal waters II. Fish. Publ. Lond. 12: $1-18$.

Nhwani, L.B., Mwaiko, S.P., Chande, A.I., Mwamsojo, G.U.J. \& Mhitu, H.A. (1993) Crustacean resource assessment in Rufiji and by-catch studies of prawn trawlers. A consultancy report submitted to National Environment Management Council (NEMC), Dar es Salaam. 113 pp.

Otto, R.S. (1986) Management and assessment of eastern Bering Sea King crab stocks. In: Jamieson, G.S. and Bourne, N. (eds) North Pacific workshop on stock assessment and management of invertebrates. Canadian Special Publication of Fisheries and Aquatic Sciences. pp. 83-106.

Potter, I.C., Chrystal, P.J. \& Loneragan, N.R. (1983) The biology of the blue manna crab Portunus pelagicus in an Australian estuary. Mar. Biol. 78: $75-85$.

Richmond, M.D., Wilson, J.D.K., Mgaya, Y.D. \& Le Vay, L. (2002) An analysis of smallholder opportunities in fisheries, coastal and related enterprises in the floodplain and delta areas of the Rufiji River, Tanzania. Rufiji Environment Management Project. REMP Technical Report No. 25. $96 \mathrm{pp}$.

Ricker, W.E. (1975) Computation and interpretation of biological statistics of fish populations. Bull. Fish. Res. Board Can. 191: 1-382.

Siegel, P.R. (1986) The exploitation of crustacean resources of Tanzania mangrove habitats. In: Mainoya, J.R. \& Siegel, P.R. (eds) Proceedings of a workshop on "Save the mangrove ecosystems in Tanzania", 21-22nd February 1986, Dar es Salaam. Faculty of Science, University of Dar es Salaam. pp. 59-69.

Smith, H. (1982) Blue crabs in South Australia: their status, potential and biology. South Australian Fishing Industry Council 6: 6-9.

Sparre, P. \& Venema, S.C. (1992) Introduction to Tropical Fish Stock Assessment. Part 1, Manual. FAO Fisheries Technical Paper, (306.1): 377 pp.

Zar, J. H. (1999) Biostatistical analysis. Fourth edition. Prentice Hall, Inc., Upper Saddle River, New Jersey. 663 pp + Appendixes. 